\title{
Parental Socio-economic Status and Attitude of Towards Cultism in Niger Delta University, Bayelsa State: Implication for Counselling
}

\author{
Agnes Ebi Maliki \\ Department of Educational Foundations, Niger Delta University, P.M.B.071, \\ Wilberforce Island, Bayelsa State, Nigeria \\ E-mail:agnesmaliki@yahoo.com
}

KEYWORDS Attitude. Cultism. Socio-economic Status. Counselling

\begin{abstract}
The study sought to examine the influence of parental socio-economics status and attitude of students towards cultism. The study was carried out in Niger Delta University, Bayelsa State, Nigeria. Five hundred and seven two (572) undergraduates were the respondents. The study revealed that parental socio-economic status significantly influences the attitude of students towards cultism. The study also indicated that students who are from high and average socio-economic status are most significantly influenced. Also counseling implications were advocated.
\end{abstract}

\section{INTRODUCTION}

The family has many functions in societies. It serves as an economic unit. It assumes responsibility for a small number of people as they move through life. Its most widely recognized function is the care and socialization of new generation. Parents are usually considered the primary agents of socialization because their influence begins so early in life. Although the family is supposed to care for, socialize and optimize the potential of children, it sometimes falls short of these goals. Children may be neglected.

It has been generally observed that people are not equal in terms of status and achievements. The existence of many strata in the society is thought to be natural. Researchers believe that socio-economics status of the students' parents has a great influence on their attitude towards objects and phenomena. Okon (2006) emphasized that socio-economics status of a person affect his or her attitude and life chances. These attitudes include: positive or negative attitude towards academic, food, dressing, drug use and abuse and the group the individual belongs.

In the same vein, Aluede and Maliki (1998) emphasized the socio-economics status of parents as a major determinant of the attitude of students towards anti-social behaviors. They further stated that students of low socio-economic families lack basic necessities of life and are both economically weak and socially depressed. Such students develop certain negative psychological feeling which often lead to frustration and could culminate in the manifestation of anti-social behaviours such as cultism. These students most often depend on psycho-active drugs and groups to carry out these anti-social behaviours. These anti-social behaviours are often employed to make up for their inadequacies of not being able to accept their poverty and low social status in the mist of their peers.

Kallaghan (1972) observed that there is a positive correlation between socio-economic status of parents and students attitudes and behaviour manifestations. He opined that the relationship between the two variables may be the economic advantage of the parents, which enables them to give their children the materials money can buy. A child from a high socioeconomic background is enriched with necessities of life, receives stimulating experiences that translates into a healthy attitude towards life generally.

The 1979 Federal Constitution, Section 35(4) defined a secret society as "... a society or association, not being a solely cultural or religious body, that uses secret signs, oaths, rites or symbols.

(a) Whose meeting or activities are held in secret;

(b) Whose members are under oath, obligation or other threat to promote the interest of its members or to aid one another under circumstances without regard to merit, fairplay or justice".

The above are the features of cultism on Nigeria University Campuses. In Nigerian campuses, there have being experiences of blood letting, massacre, maiming and killings. Cultism 
is a social ill that has placed so much debris on its victims. Innocent students suffer humiliations and molestations from cultist.

It is sad to think that cultism has continued to thrive in Nigeria university campuses, irrespective of moves and efforts by concerned organizations; university authorities and the government to salvage this situation.

The question therefore is that why are the university undergraduates joining cults, is it as result of their parental socio-economic status or what is responsible? The question guiding this study is that has parental socio-economic status any significant influence on the attitude of students towards cultism?

To answer the research question, this hypothesis is posed and tested. There is no significant influence of parental socio-economic status and students' attitude towards cultism.

\section{LITERATUREREVIEW}

Socio-economic status refer to the social and economic position occupied by parents in the society, Ivor (1978) defined it as a level made up of individuals who deem themselves equal due to similarities in family background, level of education, occupation, race and attitude towards social issues. Adebayo (1981) observed that the social status of individuals is a reflection of their economic status and he went further to explain that socio-economic status is usually a measure of the income and occupation of the individual, irrespective of his or her educational or social standing. According to him this has a tremendous influence on students' behaviour.

Caldwell (1990) posited that in the past societal norms and values pervaded the society through socialization of the young ones and even adults in the family, schools and religious institutions. He noted that norms and values relating to honesty, honour, integrity and diligence were the focus of socialization. However, he pointed out that when modernization came individualization and self-assertiveness accompanied it. These features of modernization negatively affected traditional society norms with regards to human behaviour. To this end, majority of people want to get rich quickly regardless of the means of wealth and the adverse effect on their children. This therefore encourages their children to encourage their children to engage in anti-social behaviour such as cultism.
Ezewu (1987) posited that socio-economic status can affect the academic performance of students in terms of early attendance at school, attendance of best schools and the provision of necessary materials. The students from low socioeconomic status would find it difficult to obtain his needs from his parents. So he or she may be lured into cultism in order to meet his needs. Giddens (1996) in a longitudinal study of the influence of socio-economic status of parents on children's behaviour found out that children with behavioural problems come from families with low socio-economic background.

Also Chauhan (2002) posited that, there is a positive correlation between poverty and crime involving very high earnings and very low risks. He observed that the highest percentage of criminals come from low socio-economic background. Furthermore, he observed that all persons who come from under-privilege class are criminals. The crucial factor in poor homes is that parents cannot fulfill the legitimate needs of their children. This financial incapability makes students vulnerable to the deceit of cultism, who deceives them that they will empower them and meet their needs only to end up being a cultist.

On his part, Ekpo (2000) view socio-economic status as a complex phenomenon which exerts pervasive influence on all aspect of one's life. He noted that socio-economic status is a liability that renders students vulnerable to the mischievous antics of cultists in order to make ends meet. Ukpong (1999) observed that socio-economic status has some sociological implication on the society. She explained that crime rates like cultism, gangsters, rape, street life such as hawking, prostitution and drug addiction are seriously on the increase because of poverty.

Similarly, Essien (2003) in his study on socioeconomic status and social adjustment discovered that out of the 200 students that constituted his sample only 110 representing 55 per cent were well socially adjusted to school programmes. The remaining 90 representing 45 per cent were not properly socially adjusted. The reason being that rich parents provide their children with conducive house environment, good food and other psychological needs that help them to adjust socially while the students from low socio-economic status tend not to adjust socially probably because of their homes are unstable, their means of livelihood are hardly available and as such they become withdrawn, 
socially maladjusted and as expected become highly vulnerable to cultism.

However, Denga and Denga (1998) Aluede and Maliki (1998), Anchor (1999) and Obini (2005) are of the view that some wealthy parents overpamper their children providing more than what they actually require. This, of course, provides the children with the means to purchase fire-arms and other materials used by cultists. They went further to reveal that most often parents who are of high socio-economic status have little or no time for their homes and their children are left to be brought up by house helps and significant adults around who may lead them to develop the wrong attitude towards social vices such as cultism.

\section{METHODOLOGY}

The study was carried out in Niger Delta University, Bayelsa State, Nigeria. The research design adopted for his study is Ex-post facto design.

Sample: The sample of this study consisted of five hundred and seventy-two (572) undergraduates drawn from a total population of five thousand and two (5002) undergraduates from the nine faculties of the university.

Measures: The questionnaire titled Student's Opinion Questionnaire (SOQ) was used for data collection. The instrument was made up of three parts. Part A of the instrument requested of the students personal background data. Part B of the instrument was used to elicit information on the respondents' attitude towards cultism. Part C of the instrument measured the respondents' parental socio-economic status. All the items in section B and $C$ were rated on a four-point Likert type scale ranging from strongly agree to strongly disagree. The questionnaire was content validated by professors of Psychology, Guidance and Counselling and Measurement and Evaluation. The TextRetest reliability method was adopted to determine the reliability of the instrument, which yielded reliability co-efficient estimates of 0.93 .

Procedure: The questionnaires were administered and collected by the researcher and two research assistants. For the respondents confidentiality of their responses and strict adherence to individual privacy were fully assured.

\section{ANALYSES AND RESULTS}

To establish if parental socio-economic status has any significant influence on the attitude of students towards cultism, the mean score and standard deviation of all the responses were computed, students were categorized under low parental socio-economic status, average socioeconomic status, and high parental socioeconomic status as shown in Table 1.

Table 1: Mean and standard deviation of influence of parental socio-economic status on students attitude towards cultism.

\begin{tabular}{lcc}
\hline $\begin{array}{l}\text { Parental socio- } \\
\text { economic status }\end{array}$ & $n$ & $x$ \\
\hline Low & 259 & 53.31 \\
Average & 176 & 55.77 \\
High & 137 & 58.25 \\
\hline Total & 572 & 55.25 \\
\hline
\end{tabular}

To test the hypothesis that stated that there is no significant influence of parental socio-economic status and students' attitude towards cultism. One way Analysis of Variance was used to analyze the data. The result is shown in Table 2.

The presentation of result in Table 2 shows that there is a significant influence of parental socio-economic status on students' attitude towards cultism $(\mathrm{F}=12.25 ; \mathrm{P}>.05)$. The null hypothesis was rejected because the calculated F-value of 3.00 at .05 alpha level with 2 and 569 degrees of freedom. Given the significant F-value, a detailed multiple comparison analysis using Fisher's Least Square Difference (LSD) was done to determine exactly which parental socioeconomic status influenced students' attitude towards cultism. The result of the analysis is presented in Table 3.

The result shows that students of high parental socio-economic status had a high attitude towards cultism than students of low

Table 2: One way analysis of variance of the influ-ence of parental socio-economic status on students attitude towards cultism.

\begin{tabular}{lcrrr}
\hline Sources of variable & Sum of squares & $D F$ & $M S$ & $F$ \\
\hline Between group & 2259.374 & 2 & 1129.687 & $12.25^{*}$ \\
Within group & 52463.375 & 569 & 92.203 & \\
\hline Total & 54722.748 & 571 & & \\
\hline
\end{tabular}

Significant at .05; Critical $\mathrm{F}=3.00$ 
Table 3: Fisher's LSD multiple comparison analysis of the influence of parental socio-economic status on students' attitude towards cultism.

\begin{tabular}{llcc}
\hline $\begin{array}{l}\text { Parental socio- } \\
\text { economic status }\end{array}$ & $\begin{array}{c}\text { Low } \\
(n=259)\end{array}$ & $\begin{array}{c}\text { Average } \\
(n=176)\end{array}$ & $\begin{array}{c}\text { High } \\
(n=137)\end{array}$ \\
\hline Low & $53.31^{\mathrm{a}}$ & $-2.47^{\mathrm{b}}$ & -4.94 \\
Average & $-2.63^{*}$ & -55.77 & -2.47 \\
High & $-4.87^{*}$ & $-2.26^{*}$ & 58.25 \\
MSW $=92.203$ & & &
\end{tabular}

*Significant at .05

parental socio-economic status $(\mathrm{t}=-4.87 ; \mathrm{p}>.05)$ and average parental socio-economic status $(\mathrm{t}=2.63 ; \mathrm{p}>.05)$.

The result indicated that students of high and average parental socio-economic status have a high attitude towards cultism than students of low parental socio-economic status.

\section{DISCUSSIONS}

The result revealed that there is a significant influence of parental socio-economic status on students' attitude towards cultism. This is in line with the findings of Douglas (1964), Aluede and Maliki (1998) and Okon (2006) in which the socioeconomic status of parents were opined to be a major determinant of the attitude of students towards anti-social behaviours including cultism. Also Kallaghan (1972) revealed that there is a positive correlation between socio-economic status of parents and students and behaviour manifestations.

In the same vein, Burges and Locke (1953), Denga and Denga (1998) and Aluede and Maliki (1998) posited that many parents neglected the care of their children in the hands of some house helps, in a bid to meet up the economic demands in the homes such parental neglect permeates the child's entire schooling life, because he has never known parental care, warmth, love and accommodation, he easily falls prey to the myriads of competing socializing forces most of which are in the negative direction.

Anchor (1999) and Obini (2005) revealed that some wealthy parents over-pamper their children and provide more than what they actually require. This of course provides the children with the means to purchase all items and materials needed for cultism.

\section{COUNSELLINGIMPLICATION}

This study revealed that parental socio- economic status significantly influences the attitude of students towards cultism. This has implication for counsellors. Consellors should organize workshops, seminars and symposium for parents where effective parenting will be discussed. Parents should be encouraged to visit their children in the school so that they can do a follow up of their children's progress in school and also know the kind of friends they keep. This constant check on children can sustain their educational and moral development.

Counsellors should organize orientation programmes for freshmen on the activities of cultism on campus, how cult groups operate, how to know when you are being approached to join a cult. What to do when you are being approached, and strategies devised for initiations. This awareness will definitely place freshmen on guard.

Counsellors should organize seminars, symposium and workshops for students on other social clubs on campus where they can become members and participate actively in sporting, sporting activities should be encourage among the students if these are done the students outside academic work will always be engaged and not idle because the idle mind they say is the devils workshop and the cultists may not use this as an advantage.

Counsellors should also partner with the school authorities, media, government and nongovernmental organization in sensetizing the general public on the menace of cultism and also creating awareness of the activities of cultism. These can be done through jingles on radio and television programmes in English and local languages, also by placing bill boards in strategic places in our villages, towns and cities.

\section{REFERENCES}

Andrea C, Andrea C 2003. Bullying: Facts for schools and parents. National Mental health and Education centre for children and families (NASP). http:// www.Naspcenter.org/factsheet/bully_fs.html.

Borg MG 1998. The emotional reactions to school bullies and their victims. Educational Psychology, 18: 433444

Boulton M, Undrewood K 1992. Bully/Victim problems among middle school children. British Journal of Educational Psychology, 62: 73-87.

Charach A, Pepler D, Ziegler S 1995. Bullying at school. A Canadian perspective. Educational Canada, 35: 12-18.

Craig W 1986. The relationship among aggression types, depression, and anxiety in bullies and bully/victims. Personality and Individual Differences, 45: 87-97 
Farrington DP1993. Understanding and preventing bulling. In: M Tonry (Ed.): Crime and Justice, A Review of Research, Pp.381-458.

Fisherman G, Gustavo SM, Eisikovits Z 2002. Variables affecting adolescent victimization: Finding from national Youth Survey. Western Criminology Review 3. http;//wcr.soosma.edu/v3n2/fishman.html.

Lowenstein L 1978. Who is the bully? Bulletin of the British Psychological Society, 31: 147-149.

Namsel TR, Overpeak M, Pilla RS, Ruam WJ 2001. Bullying. American medical Association, 285: 20942100 .

Olweus D 1987. School-yard bullying-grounds for intervention. School Safety, 6: 4-11.

Olweus D 1991. Bully/Victim problems and school children. Some basic facts and effects of school based intervention program. In: D Pepler, K Rubin (Eds.): The Development and Treatment of Childhood Aggression. Hillsdale, N.J.Erlbaum, pp. 411-448.

Patterson GR, Reids J, Dishion T 1992. Antisocial Boys. Eugene, OR: Castalia Press
Pepler DJ, Craig W 1997.Bullying: Research and Interventins. Youth Update. Publication of the Institute for the Study of Antisocial Youth.

Pepler DJ, Craig W, O’Connolly J, Atalas R, Sedigdeilami F, Smith C, Kent D 1997. Prevalence of Bulling and Victimization among Canadian Elementary and Middle School Children. National Crime Prevention Strategy.

Rigby K 1996. Bullying in School and What to do to it. London, England: Jessica Kingsley.

Roland E 1989. Bullying: The Scandinavian research tradition. In: D Tattum, D Lane (Eds.): Bullying in Schools. Stoke-On-Trent: Trentham, pp. 21-32.

Smith PK, Sharpe S 1994. Tackling Bulling in Your School: A Practical Handbook for Teachers. London: Routledge.

Stephenson P, Smith D 1989. Bullying in two English Comprehensive Schools. In: E Roland, E Munthe (Eds.): Bulling: An International Perspective. London: Fulton.

Thorbe C 2003. Bullying beliefs challenged. http:// www.shout.net/-rcs/eve/partch/handouts/bully.html. 